五九二著原誌雜會究研事醫堂天順

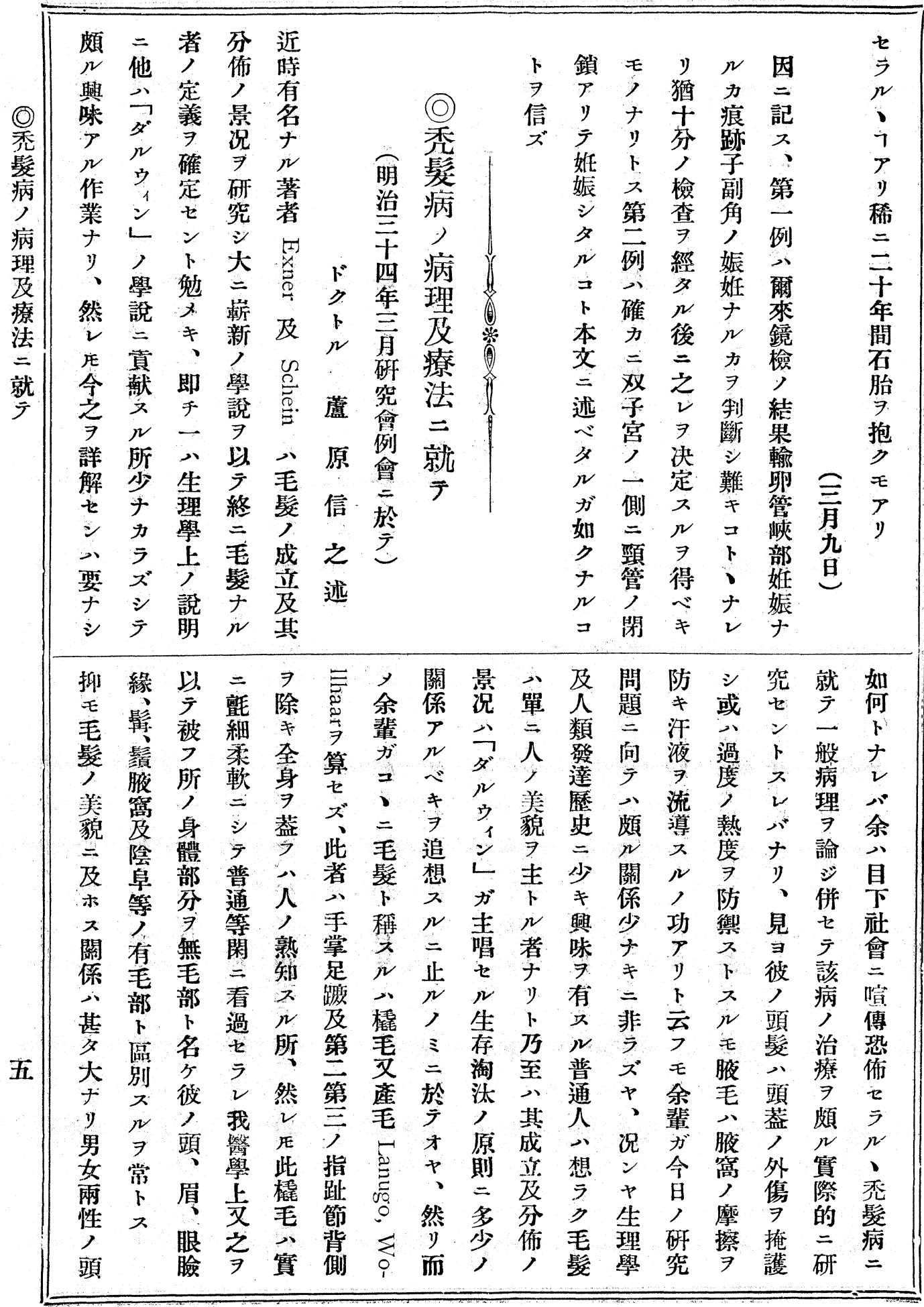




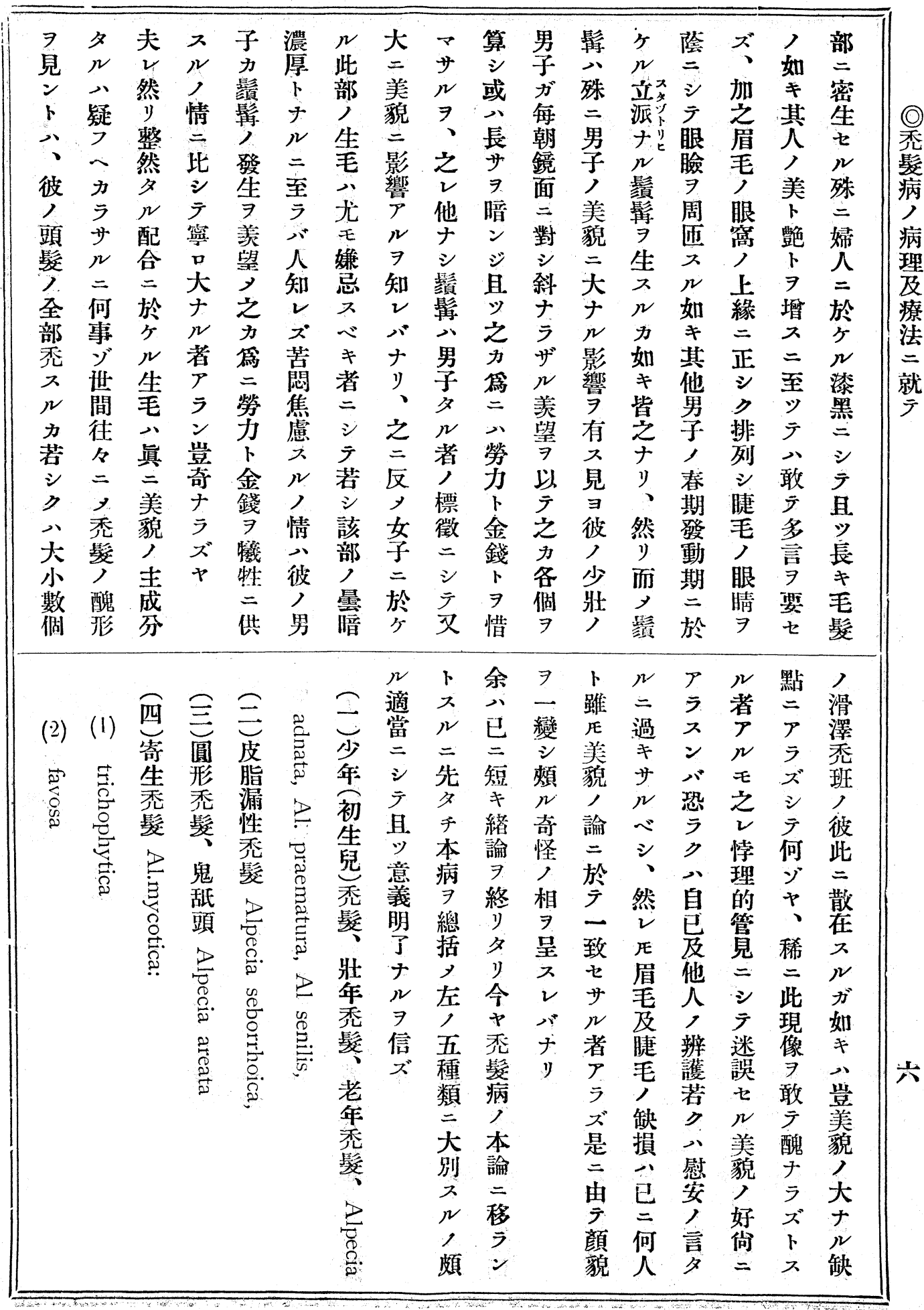




\section{七九二 著原誌雜會究研事醫堂天順}

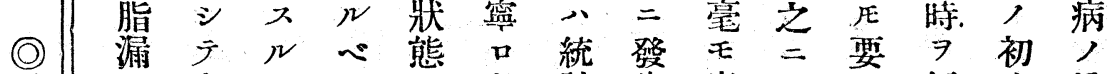

チ者 精ル 活 シ 本頂べズトー一秃

皮二查ナノテ病部ク、踓定類髮

秃三多和强各計生病区經生分

髹 シ

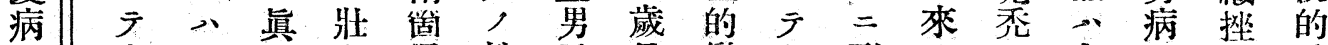

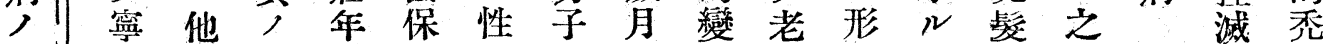

病门口, 壯秃兒能 $=$ 卜化人成 $ア$ 八

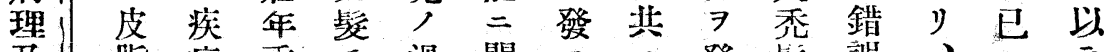

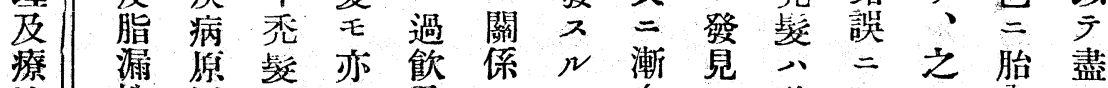

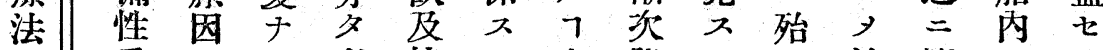

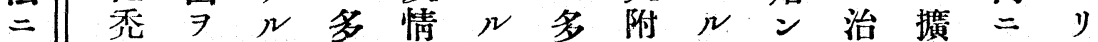

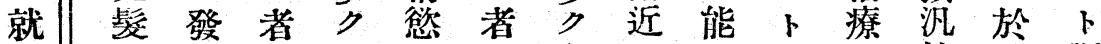

厂 二見, 八, 一年

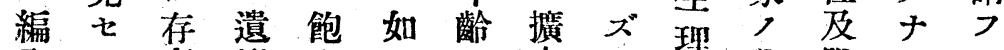

入

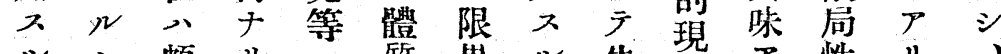

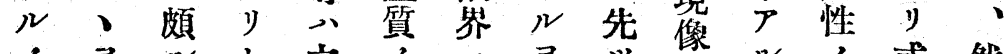

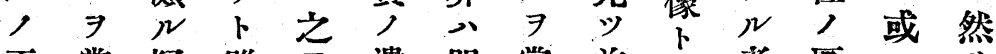

正常疑 雖 $尹$ 遺 明常前看者 區

シ $ト>E$ 補 傅ナト頍看二別分而

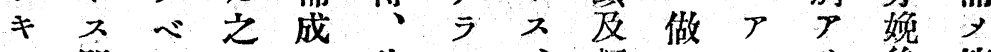

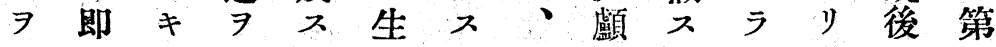

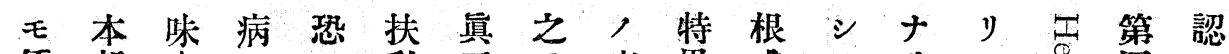

係邦少 $\Rightarrow$ 私正 $\Rightarrow$ 症異或 $\exists$ y

八三

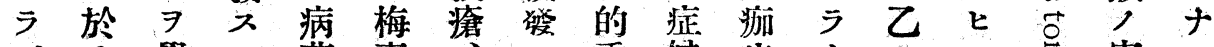

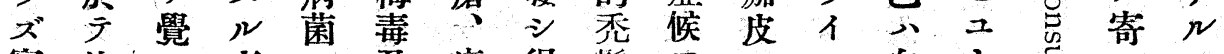

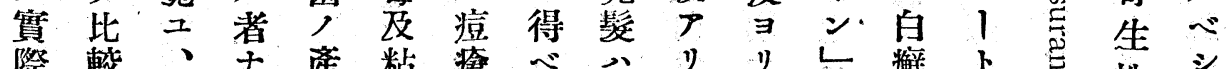

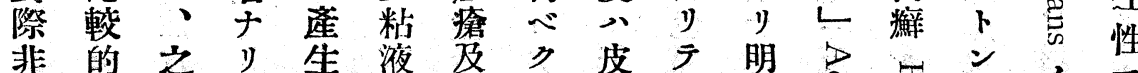

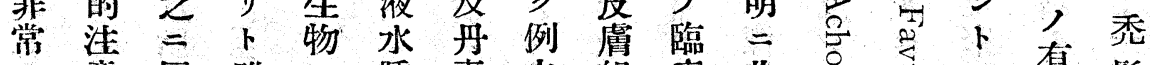

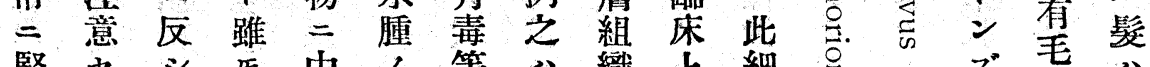

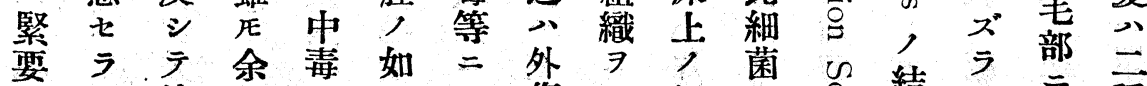

要 $、$ 第 余 毒 如

シ ズ 令 ラ 全 テ 壤 別證 导: 果ス發ア

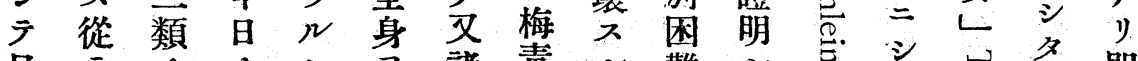

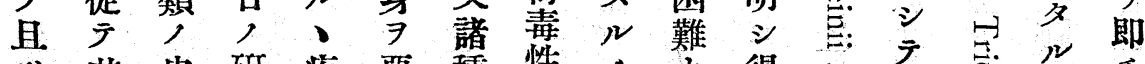

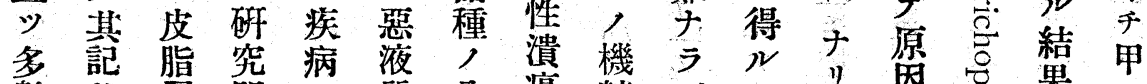

數 載 漏 問 $\cdots$ 質 全瘍轉 ズ, 少然总果

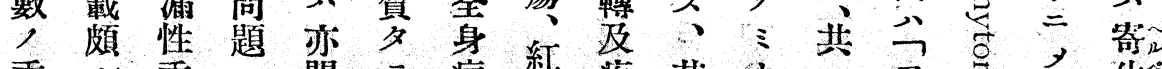

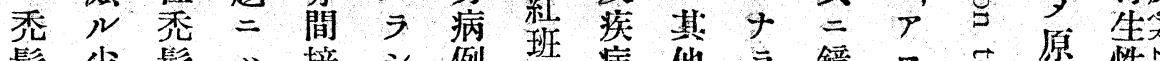

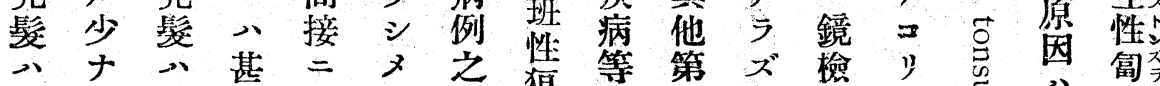

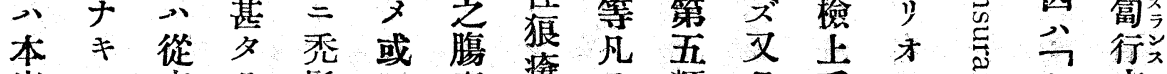

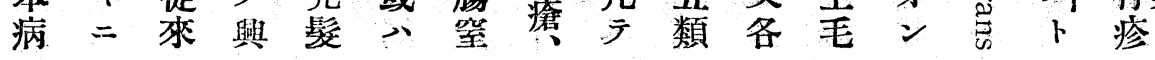


諕十四百三第誌雜會究研事醫堂天順

八九二

\begin{tabular}{|c|c|c|c|c|c|c|c|c|c|c|c|c|c|c|c|c|}
\hline , & ナ & ナ & 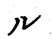 & 脂 & 秃 & & 7 & 秃 & 性 & 以 & 入 & $v$ & $\overline{7}$ & 秃 & , & $=$ \\
\hline 筥 & $r$ & $N$ & 纷 & 漏 & 㢡 & $\frown$ & 終 & 琵 & 秃 & 上 & $N$ & 今 & x & 㹂 & - & 由 \\
\hline$\rightarrow$ & 顯 & $\sim$ & 泌 & ト &.$\prime$ & $\mathcal{C}$ & ラ & 7 & 髮 & ノ & カ & $\uparrow$ & 然 & 亦 & 日 & 來 \\
\hline 致 & 微 & シ & 官 & $>0$ & 原 & 皮 & ン & 秒 & 及 & 理 & 如 & - & $v$ & 屢 & 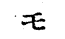 & x \\
\hline$\bullet$ & 鏡 & $\overrightarrow{7}$ & 能 & 皮 & 因 & 脂 & $\mathbf{F}$ & $ヤ$ & 第 & 由 & $\eta$ & 派 & $\mathscr{E}$ & 見 & 忽 & $N$ \\
\hline ズ & 檢 & $y$ & 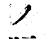 & 脂 & 中 & 漏 & ス & 詳 & 五 & $=$ & 思 & ' & 本 & $N$ & 緒 & 7 \\
\hline & 查 & + & 障 & 腺 & 最 & 性 & & 細 & 類 & 基 & $\rightarrow$ & 士 & 病 & 所 & $=$ & $\gamma$ \\
\hline & ' & L & 害 & J. & E & 秃 & & $=$ & 症 & キ & シ & $=$ & $=$ & $=$ & 附 & $N$ \\
\hline & 成 & $C^{\prime}$ & ' & 分 & 噟 & 髮 & & 第 & 侯 & 以 & 厶 & 八 & 就 & シ & $x$ & 7 \\
\hline & 蹟 & $\vec{\Xi}$ & ミ & 泌 & ナ & 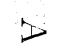 & & $\equiv$ & 否 & F & $N$ & 否 & $\bar{J}$ & $\bar{\tau}$ & ベ & 以 \\
\hline & 7 & 2 & $=$ & 過 & $N$ & 5 & & 類 & 䯮 & 余 & $=$ & 髮 & 八 & 醫 & 力 & テ \\
\hline & 以 & 八 & $P$ & 剩 & 著 & $\overrightarrow{0}$ & & 圓 & 7 & 八 & 至 & 病 & 巳 & 家 & ラ & 見 \\
\hline & $\bar{y}$ & 本 & ラ & 症 & 八 & $\frac{\Omega}{2}$ & & 形 & 論 & 第 & $v$ & ト & $=$ & , & ザ & $v$ \\
\hline & $z$ & 症 & 天゙ & ナ & 本 & & & 秃 & ス & - & リ & 八 & 此 & 之 & $N$ & バ \\
\hline & $\exists$ & $\jmath$ & シ & リ & 症㱏 & $\&$ & & 筙 & $\mu$ & 類 & & 則 & 䡡 & $=$ & 者 & 該 \\
\hline & 證 & 炎 & $\bar{\gamma}$ & ト & 夕 & ? & & 7 & $\exists$ & 年 & & 千 & 的 & 逢 & ナ & 病 \\
\hline & セ & 性 & 㖤 & 踓 & $N$ & $\vec{\sigma}$ & & 概 & 止 & 龄 & & 單 & 詳 & 遇 & $N$ & 1 \\
\hline & ? & $=$ & 微 & E & 7 & $\vec{B}$ & & 論 & x & 否 & & $=$ & 細 & x & へ & 研 \\
\hline & 然 & 就 & $=$ & 恐 & 疑 & & & シ & 第 & 瑟 & & 圓 & $=$ & $N$ & シ & 塋 \\
\hline & $v$ & テ & 經 & ラ & ナ & & & $\bar{\gamma}$ & 二 & ' & & 形 & 記 & 7 & ' & $\rightarrow$ \\
\hline & $\mathscr{E}$ & 主 & 過 & $\eta$ & シ & & & 以 & 類 & 第 & & 秃 & 載 & 甚 & 第 & 實 \\
\hline & 末 & 張 & ス & $\rightarrow$ & V & & & $\overline{\bar{\gamma}}$ & 皮 & 西 & & 琵 & 紹 & 3 & 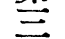 & 地 \\
\hline & タ & シ & $n$ & 單 & 抑 & & & 此 & 脂 & 類 & & $\exists$ & 介 & 少 & 類 & 治 \\
\hline & 諸 & 精 & 炎 & 純 & 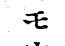 & & & 研 & 漏 & 奇 & & 意 & $\rightleftarrows$ & ナ & 圓] & 療 \\
\hline & 家 & 密 & 症 & ナ & 皮 & & & 突 & 性 & 生 & & 味 & ラ & 力 & 形 & 家 \\
\hline 七 & 故 & 從 & 症 & $=$ & 病 & 八 & 套 & $\boldsymbol{\gamma}$ & I & $\rightarrow$ & 八 & 本 & & & 種 & 本 \\
\hline ラ & $=$ & $\bar{J}$ & 八 & 由 & 的 & ル & $=$ & y & 原 & 人 & 度 & 症 & $\frac{0}{8}$ & (1) & $=$ & 症 \\
\hline 2 & 皮 & 瘙 & 初 & $\bar{z}$ & ナ & 之 & 於 & v & 因 & $=$ & 脂 & 八 & os & 擴 & 區 & 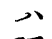 \\
\hline 其 & 脂 & 棒 & 期 & 除 & ラ & $V$ & $\bar{\tau}$ & 乙 & r & 於 & 過 & 頗 & $\tilde{\Omega}$ & 沉 & 別 & 種 \\
\hline ' & 漏 & ノ & $=$ & 去 & ズ & 著 & 灰 & $\therefore$ & ナ & $\bar{\gamma}$ & 溢 & $N$ & $=$ & 性 & シ & 々 \\
\hline 脫 & 症 & 度 & 瘟 & 七 & 之 & 明 & 白 & 則 & $N$ & 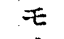 & シ & 蔓 & $\Xi$. & 慢 & $\bar{\gamma}$ & ' \\
\hline 毛 & I & $\exists$ & 㾕 & ラ & $=$ & ナ & 色 & 千 & 7 & 生 & $\bar{\gamma}$ & 延 & 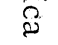 & 性 & 論 & 形 \\
\hline 7 & 第 & 賭 & 及 & $N$ & 反 & $N$ & 扁 & 無 & $\boldsymbol{\gamma}$ & 活 & 著 & 七 & $\cong$ & 皮 & セ & 式 \\
\hline 繼 & - & シ & 緊 & べ & シ & 標 & 本 & 數 & y) & ノ & シ & 22 & $\vec{\exists}$ & 脂 & ע & 7 \\
\hline 發 & 期 & 終 & 張 & 5 & テ & 徵 & I & 1 & 或 & 牀 & $\eta$ & 疾 & D్ & 漏 & r & 以. \\
\hline ス & 品 & $=$ & ' & $v$ & 病 & ナ & 小 & 人 & 八 & 態 & 毛 & 病 & & 性 & ス & $\bar{\Sigma}$ \\
\hline$\mu$ & 單 & 症 & 感 & バ & 的 & $y$ & 片 & $=$ & 乾 & $=$ & 髮 & $=$ & & 秃 & & 現 \\
\hline$=$ & $=$ & 把 & $\boldsymbol{\gamma}$ & 此 & ノ & 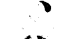 & 即 & 於 & 性 & 由 & 7 & シ & & 䯮 & & $N$ \\
\hline 至 & 3 & 1 & y & 際 & 3 & 然 & 千 & $\bar{\gamma}$ & $\Omega$ & y & 輝 & $\bar{\gamma}$ & & & & 余 \\
\hline N & if & 痕 & 然 & 敢 & $\widehat{i t}$ & $v$ & 3 & 見 & 8 & $\bar{\jmath}$ & カ & 之 & & ? & & 八 \\
\hline$\vec{P}$ & $L$ & 踏 & 2 & $\overline{\bar{T}}$ & L & E & $\widehat{H}$ & $N$ & s. & 差 & シ & $=$ & & $\ddot{0}$ & & 便 \\
\hline 驚 & 症 & $\exists$ & $\mathscr{E}$ & 嚜 & $\mathcal{モ}$ & 凡 & ᄂ & 所 & 8 & $\gamma$ & $\triangle$ & 港 & & 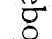 & & 宜 \\
\hline$\overline{5}$ & P & 認 & 病 & 診 & 梳 & $\bar{\gamma}$ & $\Omega$ & 1 & نمع. & $y$ & ע & 乾 & & $\exists$ & & ) \\
\hline 治 & シ & 厶 & 症 & ᄌ & 髮 & ב & ㅋ. & 被 & , & 本 & $\because$ & 1 & & o. & & 篇 \\
\hline 7 & $\bar{T}$ & $N$ & 進 & 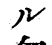 & 或 & 3 & $\Xi$ & 服 & 前 & 症 & 人 & 兩 & & $\stackrel{8}{8}$ & & $x$ \\
\hline 乙 & 等 & 7 & 步 & 勿 & \# & if & 1 & , & 驅 & 3 & 種 & 性 & & 0 & & 之 \\
\hline 7 & 䦥 & 得 & x & $v$ & 石 & 2 & ナ & 襟 & 症 & 值 & 經 & $\gamma$ & & & & $\exists$ \\
\hline 7 & $=$ & べ & $N$ & 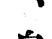 & 龉 & 必 & $\mathscr{\Psi}$ & 或 & ナ & $=$ & 緯 & y & & $\rightleftharpoons$ & & 左 \\
\hline 常 & 看 & * & 用 & 自 & 洗 & シ & $j$ & $>$ & $\nu$ & 否 & 及 & ப & & $\leftrightarrows$ & & , \\
\hline$r$ & 過 & & $\rightarrow$ & 覺 & 绦 & 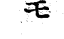 & 現 & 外 & 7 & 鬆 & 同 & 甲 & & $\rightarrow$ & & 二 \\
\hline
\end{tabular}




\section{九九二著原誌科會聟研事嚳堂天順}

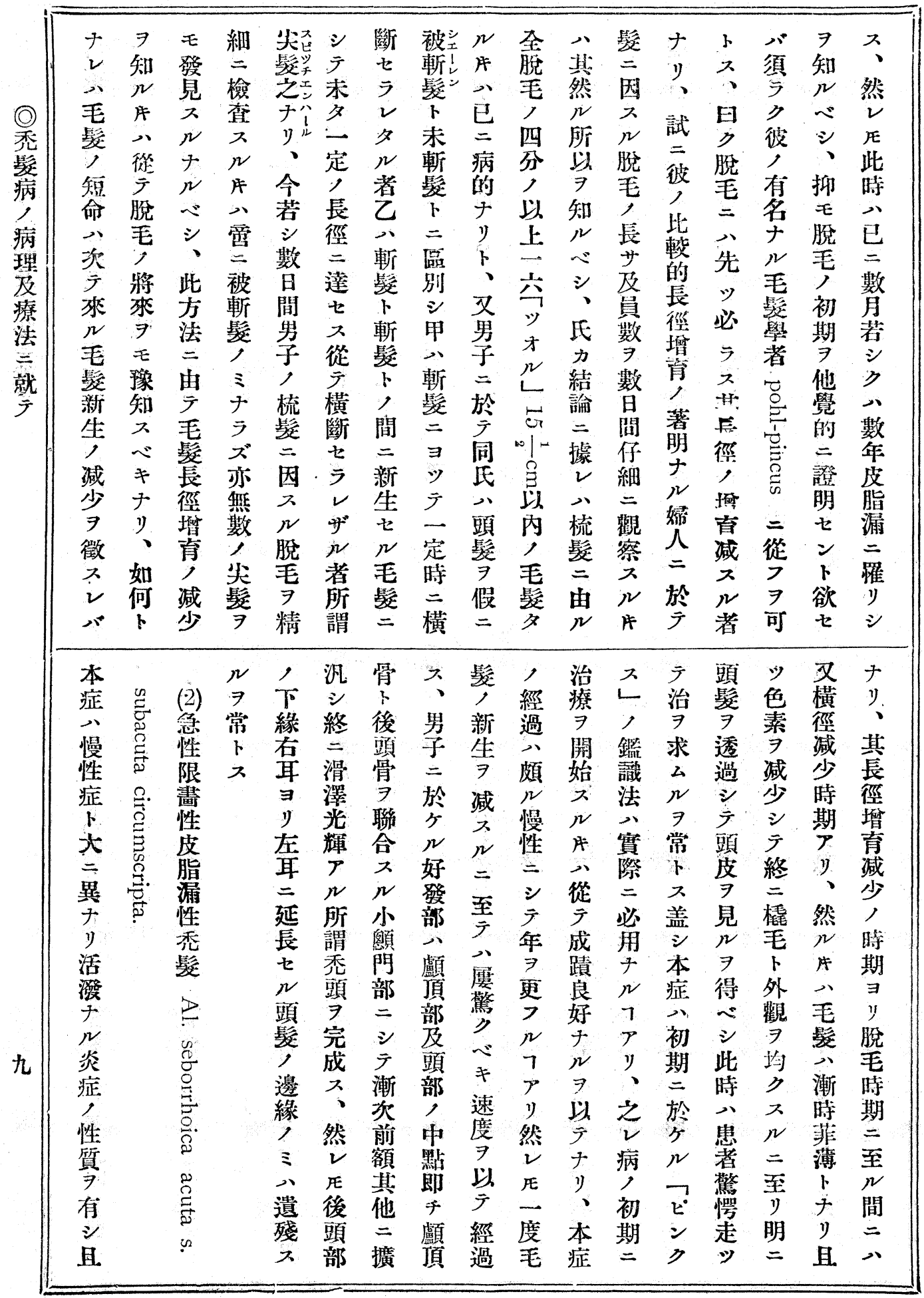


號十泗百三第誌誰會究研事醫堂天順

OOझ

\begin{tabular}{|c|c|c|c|c|c|c|c|c|c|c|c|c|c|c|c|c|}
\hline 偶 & 罩 & $\gamma$ & 奶 & 蔓 & $n$ & $=$ & 原 & 整 & 秃 & x & 眉 & 認 & 9 & 認 & 你 & ツ \\
\hline 然 & 延 & $N$ & 何 & 延 & $p$ & x & 因 & 規 & x & $B_{0}$ & 毛 & 公 & 呈 & 厶 & 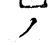 & 限 \\
\hline 家 & セ & $\nabla$ & 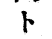 & 7 & 才 & $x$ & $\therefore$ & 的 & $N$ & 眉 & 慷 & べ & $\dot{*}$ & 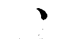 & 旕 & 畫 \\
\hline 羿 & $N$ & 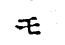 & + & $N$ & $N$ & 2 & 末 & 炎 & 八 & 毛 & 毛 & $\neq$ & 時 & 病 & $\Rightarrow$ & ᄌ \\
\hline$=$ & 聅 & 知 & $v$ & 景 & カ & L & 夕 & 症 & 甚 & ; & 藝 & 地 & 1 & 性 & 以 & 、 \\
\hline 多 & 病 & $n$ & バ & 况 & $=$ & ナ & 不 & I & 及 & 殊 & 髹 & 點 & シ & 淮 & $\bar{\gamma}$ & 即 \\
\hline 墢 & ナ & べ & 體 & 之 & x & u & 明 & 現 & 稀 & $=$ & $=$ & 于 & $\vec{\jmath}$ & 步 & 被 & 千 \\
\hline ス & $N$ & 力 & 質 & f & $x$ & $\ngtr$ & $\tau$ & 㶵 & t & 外 & 來 & シ & > & त & $>$ & 局 \\
\hline 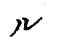 & 力 & ラ & 的 & リ & ע & 否 & y & $\exists$ & y & 端 & N & & 所 & $\nu$ & $v$ & 部 \\
\hline 7 & 故 & ザ & 關 & V & ᄂ & $\vec{p}$ & 主 & 見 & V & $=$ & 本 & & 謂 & 牛 & z & $>$ \\
\hline ナ & $=$ & $N$ & 係 & 然 & 7 & $=$ & + & $\pi$ & 䯮 & 好 & 病 & & 度 & $\therefore$ & $\bar{F}$ & 毛 \\
\hline シ & タ & $\exists$ & $\exists$ & $v$ & 想 & $\gamma$ & $N$ & 7 & 䉰 & 發 & $\rightarrow$ & & 筞 & 毛 & 㔀 & 莀 \\
\hline EE & $r$ & W & リ & E & $\therefore$ & リ & 目 & 少 & $=$ & シ & 菛 & & 漏 & 口 & 離 & $\Rightarrow$ \\
\hline 七 & I. & $\bar{j}$ & $y$ & え & シ & 倌 & 早 & F & 來 & 睷 & 覀 & & 性 & $>$ & त & 荟 \\
\hline 少。 & 傳 & ナ & 毛 & 7 & $\Delta$ & 嵒 & , & シ & $N$ & 毛 & 性 & & 混 & 㡵 & $\nu$ & 着 \\
\hline$n$ & 染 & y & 鬊 & 以 & $v$ & 床 & 問 & & $\rightarrow$ & $\therefore$ & $=$ & & 疹 & 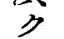 & 牛 & 七 \\
\hline$=$ & 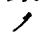 & 况 & $=$ & $\bar{\gamma}$ & 7 & 的 & 題 & & 頗 & 小 & シ & & $\overline{7}$ & 開 & ; & $N$ \\
\hline 於 & 關 & 2 & 同 & , & $p$ & > & ני & & $N$ & 兒 & $\bar{\gamma}$ & & 續 & 大 & 㕆 & 稍 \\
\hline $\bar{J}$ & 係 & 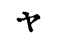 & 棓 & $\Sigma$ & リ & 桱 & $\neg$ & & 稀 & $=$ & 炎 & & 發 & シ & 濕 & $p$ \\
\hline 才 & ナ & 皮 & $\gamma$ & 證 & 殊 & 歌嘫 & ミ & & $=$ & 於 & 症 & & X & 管 & 潤 & 厚 \\
\hline$p$ & シ & 脂 & 聯 & 入 & $=$ & 公 & $\eta$ & & シ & $\bar{\gamma}$ & 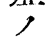 & & 、 & 3 & 性 & $\neq$ \\
\hline 活 & ト & 漏 & 通 & べ & 家 & 婁 & 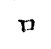 & & $\bar{j}$ & 屢 & 性 & & 好 & 如 & , & 不 \\
\hline 紧 & ス & 八 & 的 & カ & 族 & $\begin{array}{c}8 \\
145\end{array}$ & 才 & & 此 & 貧 & 狀 & & 發 & $\neq$ & 皮 & 浶 \\
\hline 最 & $N$ & 甚 & 理 & $\overline{7}$ & 的 & 此 & N & & 際 & $n$ & $\Rightarrow$ & & 部 & 外 & 虜 & 灰 \\
\hline ウ & E & 及 & 由 & ズ & $=$ & $\Sigma$ & ガ & & 八 & 所 & 有 & & P & 觀 & $\Rightarrow$ & 白 \\
\hline ע & 病 & $N$ & 八 & 病 & ラ & i & 得 & $=$ & $z$ & 䜿 & $=$ & > & ڤั & ע & タ & ン \\
\hline 然 & 原 & 所 & 頗 & $\rightarrow$ & 来 & $\bar{\gamma}$ & $\sim$ & シ & $v$ & 病 & 缺 & ズ & ש & $L$ & $y$ & + \\
\hline$v$ & 小 & タ & $N$ & 各 & 3 & 本 & シ & 厂 & 皮 & 即 & $\Rightarrow$ & 故 & $=$ & 7 & V & L \\
\hline$E$ & 以 & $y$ & 䈏 & 茞 & 凡 & 症 & 、 & 其: & 膚 & F & $\rightarrow$ & $=$ & 卜 & 發 & $\neg$ & $c$ \\
\hline 全 & 上 & & $\exists$ & 床 & $\bar{J}$ & $\Rightarrow$ & 氏 & 細 & $=$ & 皮 & 頗 & 又 & 名 & 見 & ウ & $\vec{E}$ \\
\hline 身 & I & & 得 & 上. & , & 發 & $\therefore$ & 菌 & 於 & 脂 & $N$ & 種 & $\begin{array}{l}\text { 口 } \\
5\end{array}$ & $\begin{array}{l}\text { シ } \\
=\end{array}$ & $\ddot{z}$ & $\overline{2}$ \\
\hline ; & 如 & & 3 & 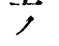 & 反 & ス & 之 & 八 & 5 & 漏 & 遺 & 接 & 夕 & $\bar{\gamma}$ & な & 上 \\
\hline 異 & $\eta$ & & $N$ & 特 & 對 & $n$ & $\exists$ & 末 & $n$ & 性 & 憾 & $\Rightarrow$ & 1) & $\vec{a}$ & L & H \\
\hline 常 & 恐 & & 者 & 徵 & 著 & $\Rightarrow$ & 培 & 及 & 5 & $E$ & 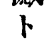 & 試 & , & $\exists$ & 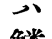 & $7^{\circ}$ \\
\hline 丙 & $\bar{j}$ & & $=$ & $\gamma$ & $\Rightarrow$ & 見 & 養 & 否 & 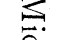 & 亦 & ス & 公 & 然 & 3 & 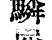 & p \\
\hline 藏藏 & $\eta$ & & $\gamma$ & $v$ & 制 & \& & シ & 七 & $?$ & 蒷 & r & 能 & $v$ & $\stackrel{\circ}{\circ}$ & 管 & 1 \\
\hline , & $\rightarrow$ & & ラ & $=$ & 服 & リ & 且. & サ & $\frac{O}{2}$ & 眥 & 所 & $\rightarrow$ & E & ஜ் & 中 & $L$ \\
\hline 疾 & $\neg$ & & ズ & $\varepsilon$ & $\pi$ & • & ツ & $N$ & อి. & 秃 & ナ & ズ & 今 & 8 & $=$ & $\infty$ \\
\hline 患 & ₹ & & 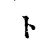 & 係 & 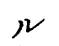 & 然 & 產 & $=$ & 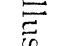 & 監 & y & 依 & 日 & $\underset{\approx}{\approx}$ & f. & $\tilde{\sigma}$ \\
\hline 及 & " & & $\therefore$ & $\overline{3}$ & 能 & $v$ & 生 & 賞 & & $\mp$ & 7 & $\overline{\bar{J}}$ & 汽 & & 種 & § \\
\hline 生 & $\vec{z}$ & & 多 & ズ & $\therefore$ & $\mathscr{E}$ & 七 & $\bar{J}$ & , & 同 & F。 & 細 & 牙: & r & 3 & $\vec{\jmath}$ \\
\hline 萿 & 才 & & $y$ & 同 & ズ & 此 & N & 特 & 毒 & - & ブ & 菌 & 純 & 名 & ミ & ฉี \\
\hline$\gamma$ & נ & & , & - & 就 & 有 & 毒 & $=$ & 質 & , & 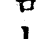 & 學 & 粹 & 5 & $\eta$ & 八 \\
\hline 狀 & $\begin{array}{l}\text { 力 } \\
=\end{array}$ & & 臨 & 原 & 中 & 零 & 質 & 多 & $=$ & 病 & 1 & E & 培 & 他 & a & 之 \\
\hline 態 & $=$ & & 床 & 因 & 種 & f & $\bar{\exists}$ & 数 & 由 & 原 & $\therefore$ & 有 & 養 & & オ & 力 \\
\hline 等 & $\hat{x}$ & & 家 & $F$ & \& & $N$ & 動 & $\exists$ & $\bar{j}$ & $f$ & 種 & 力 & 年 & 7 & $N$ & 說 \\
\hline$\therefore$ & $x$ & & , & y & ナ & 挆 & 物 & 認 & 發 & $y$ & s & f & 達 & |20 & ガ & 明 \\
\hline 本 & 2 & & 唱 & r & $N$ & 驗 & $=$ & 么 & ג & F & ナ & $N$ & ス & & $=$ & $\Rightarrow$ \\
\hline 症 & $F$ & & 檤 & ス & 秃 & 者 & 試 & N & $N$ & 七 & IV & 證 & 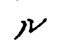 & $\vec{Q}$ & ス & 與 \\
\hline 1 & ラ & & ス & $\mathcal{L}$ & 髮 & $\pi$ & 驗 & 7 & 者 & $y$ & 秃 & 明 & 能 & تّ & $\not$ & $\sim$ \\
\hline
\end{tabular}




\section{一○三著原绫雜會究研事醫堂天順}

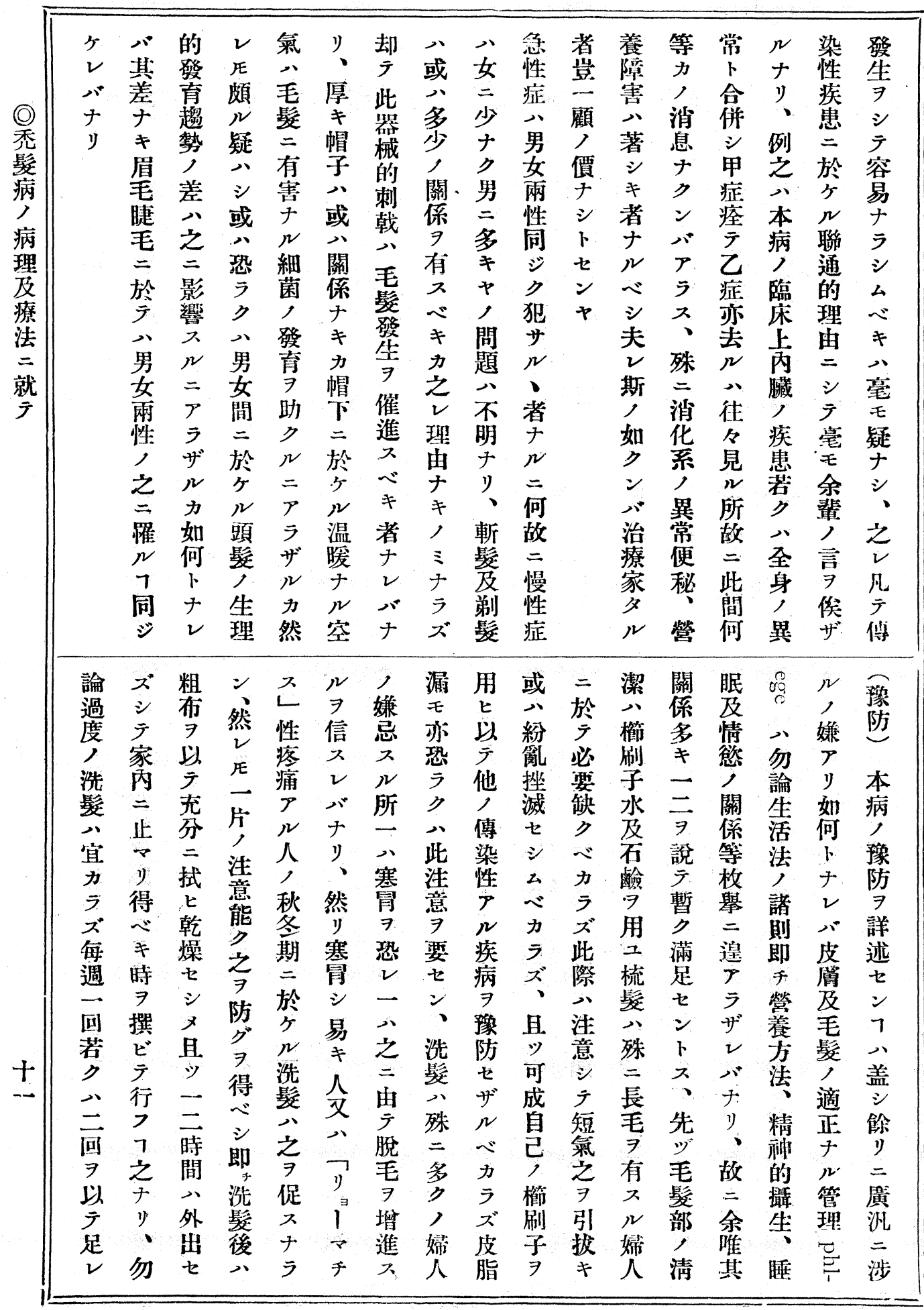




\begin{tabular}{|c|c|c|c|c|c|c|c|c|c|c|c|c|c|c|c|c|}
\hline 小 & ス & $\bar{\gamma}$ & 合 & 殊 & ナ & $=$ & $\bar{\jmath}$ & $\eta$ & 泡 & $z$ & & & & $\neg$ & 者 & リ \\
\hline 先 & $n$ & シ & $=$ & $=$ & $\overline{3}$ & ス & 洗 & シ & 沫 & $\exists$ & & & & (7) & f & $卜$ \\
\hline ๗ & 7 & 么 & $\exists$ & 血 & x & $n$ & 滌 & $\bar{J}$ & $=$ & 辰 & 剌 & 酒 & 加 & ᄀ & $y$ & $\pi$ \\
\hline 油 & 以 & ぶ & $y$ & 行 & ' & $>$ & ス & 琶 & 至 & 毛 & 賢 & 精 & 里 & 亏 & $z$ & べ \\
\hline$\exists$ & $\bar{\gamma}$ & シ & $\bar{\gamma}$ & $\exists$ & 显 & 利 & బ゙ & $F$ & 5 & 且. & 恎 & $\therefore$ & 石 & 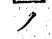 & $=$ & シ \\
\hline 以. & 3 & 之 & $>$ & 盛 & ト & $\gamma$ & シ & シ & シ & ツ & 兒 & & 簽 & 石 & 八 & 、 \\
\hline $\bar{\gamma}$ & 少 & $v$ & 石 & $=$ & シ & $y$ & Z & V & $\Delta$ & 密 & 油 & & & 燐 & 精 & 濳 \\
\hline 昮 & I & 清 & 鹼 & シ & $\bar{\gamma}$ & 微 & $v$ & 然 & 此 & 广 & & & & 精 & 製 & 榛 \\
\hline 7 & 泩 & 潔 & F & 莈 & 此 & 温 & - & $\mathrm{N}$ & 際 & $x$ & & & & $\therefore$ & 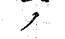 & $=$ \\
\hline 除 & 意 & 刺 & 塗 & 膚 & $j$ & $>$ & $\therefore$ & 後 & 多 & 7 & & & & $\Phi$ & 碌 & 當 \\
\hline$\neq$ & $\exists$ & 戟 & 擦 & 神 & 洗 & 皮 & 清 & $=$ & 量 & $\begin{array}{l}7 \\
=\end{array}$ & & & & $\vec{\Phi}$ & 石 & $y$ \\
\hline 然 & 要 & $\jmath$ & 洗 & 經 & 棌 & 䖉 & 潔 & 虫 & $\vec{\jmath}$ & $\overline{3}$ & & & & in & 睑 & 不 \\
\hline$N$ & x & 度 & 策 & $\exists$ & 後 & $\exists$ & 3 & 䎛 & $\overrightarrow{7}$ & 子 & & & - & 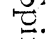 & 10 & 鹼 \\
\hline 後 & ' & $\Rightarrow$ & ر & 活 & 劣 & 遲 & 度 & $\jmath$ & $\gamma$ & 2 & 3 & 7 & 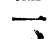 & $\stackrel{\Xi}{\rightleftarrows}$ & $\mathscr{N}$ & $\exists$ \\
\hline 過 & 基 & 高 & 間 & 動 & 木 & 慢 & $\exists$ & 湛 & N & $=$ & & 0 & 0 & $\underset{n}{n}$ & 8 & 用 \\
\hline 脂 & 隠 & $P$ & $=$ & 七 & 冷 & ナ & 高 & $\sim$ & $\vec{u}$ & 付 & & & $\bigcirc$ & > & 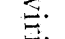 & $\geq$ \\
\hline 性 & 性 & シ & 於 & シ & 水 & $\overline{5}$ & $\not x$ & 得 & $n$ & シ & & & & 甚 & $\stackrel{20}{\Rightarrow}$ & $N$ \\
\hline 石 & 及 & 厶 & $\bar{J}$ & 么 & I & シ & 他 & 心 & ${ }^{N}$ & 頡 & & & & ダ & & $\therefore$ \\
\hline 觑 & 惡 & $N$ & $=$ & $N$ & 灌 & 厶 & 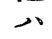 & 平 & $\bar{\exists}$ & 度 & & & & 帛 & $\exists$ & 最 \\
\hline 7 & 急 & モ & $\equiv$ & $ノ$ & 溉 & $N$ & 皮 & 塺 & 用 & 及 & & & & 于 & 撰 & 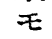 \\
\hline 以 & 性 & 屢 & 時 & 利 & $\exists$ & 琶 & 膚 & $\gamma$ & ב & 頭 & & & & $y$ & $7^{*}$ & 當 \\
\hline テ & 皮 & 荻 & 間 & $\gamma$ & 行 & $\gamma$ & 血 & 溜 & $N$ & 髮 & & & & & œ & $\exists$ \\
\hline 疑 & 脂 & 症 & $\exists$ & y & 7 & リ & 行 & 水 & $\rightarrow$ & $=$ & & & & & シ & 得 \\
\hline 睬 & 漏 & $\exists$ & 隔 & ' & 之 & $\bar{\gamma}$ & $\Rightarrow$ & $\exists$ & 價 & 塗 & & & & & 彼 & 3 \\
\hline シ & $=$ & 發 & タ & 筀 & $\nu$ & 良 & 良 & 以 & 䯩 & 擦 & & & & & $y$ & N \\
\hline$\exists$ & ノ & 數 & 際 & 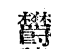 & $\bar{\gamma}$ & 足 & 毛 & $\overparen{\text { 病 }}$ & 等 & 其: & & & & & 7 & 續 \\
\hline D. & 霹 & 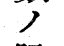 & 治 & 積 & 倘 & ラ & 즈 & $\begin{array}{l}\text { 獠 } \\
\text { 洼 }\end{array}$ & 分 & 他 & ワ & 澱 & 酸 & 保 & 去 & 發 \\
\hline $\bar{J}$ & $x$ & 脫 & 療 & 7 & 水 & サ & 然 & 法 & $\exists$ & 白 & ゼ & 粉 & 化 & 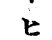 & $\vec{y}$ & 七 \\
\hline ナ & 再 & 毛 & 家 & 排 & 毛 & N & $v$ & 度 & 用 & 降 & y & & 亞 & チ & 次 & $\nu$ \\
\hline y & ビ & $\boldsymbol{\gamma}$ & 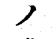 & 除 & 囊 & $\gamma$ & $\mathscr{E}$ & 脂 & E & 永 & ン & & 鉛 & 才 & $\overline{\bar{\gamma}}$ & 濕 \\
\hline 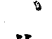 & 醫 & $N$ & 决 & シ & 中 & $ミ$ & Z & 漏 & 殊 & 軟 & & & & 1 & 左 & 疹 \\
\hline 此 & $=$ & べ & シ & 以 & $\doteq$ & ナ & 2 & J & $=$ & 䓨 & & & & 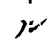 & 法 & $=$ \\
\hline 時 & 隶 & ₹ & $\bar{\gamma}$ & テ & 存 & ラ & 單 & 進 & $=$ & & & & & & $\exists$ & > \\
\hline 期 & $\overline{7}$ & $\exists$ & 忘 & 新 & ᄌ & 주 & $\underline{=}$ & $=$ & 1 & 亞 & $\rightarrow$ & & & & 處 & 適 \\
\hline$\rightarrow$ & x & 懇 & $N$ & 毛 & K & 置 & 器 & $\bar{J}$ & 四 & 鉛 & $\Omega$ & $\overrightarrow{-}$ & $\rightarrow$ & & ス & 當 \\
\hline 佾 & シ & 翁 & べ & 發 & 者 & D & 械 & 秃 & $\%$ & 花 & 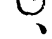 & $\checkmark$ & $\rightarrow$ & 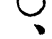 & $n$ & $\gamma$ \\
\hline ホ & $\bar{\gamma}$ & シ & カ & 生 & 脫 & 必 & 的 & 髮 & 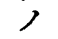 & $\nabla$ & 0 & 五 & 五 & 五 & $\exists$ & 軟 \\
\hline 每 & 却 & 置 & ラ & $ノ$ & 離 & 要 & 動 & 症 & 硫 & Ł & & & & & 良 & 膏 \\
\hline 邀 & $\bar{J}$ & $\eta$ & ザ & 㗢 & シ & ナ & 作 & $=$ & 黄 & y & 7 & 安 & 酸 & ザ & P & 或 \\
\hline- & 治 & 7 & $N$ & 處 & 之 & y & J & 移 & 乳 & ע & ゼ & 息 & 化 & 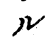 & f & 八 \\
\hline$=$ & 療 & 之 & $\longrightarrow$ & $\exists$ & $=$ & V & 結 & $\pi$ & $\exists$ & 軟 & y & 酸 & 惡 & チ & x & 7 \\
\hline 回 & $\exists$ & f & 初 & 與 & 因 & 即 & 果 & + & 混 & 膏 & 2 & $\mathrm{~J}$ & 鉛 & 1 & & バ \\
\hline ' & 繼 & y & 回 & 7 & $\bar{y}$ & $\dot{f}$ & $=$ & 涨 & $\pi$ & & & & & $N$ & & र \\
\hline 洗 & 續 & 然 & ノ & $\nu$ & 其 & 已 & シ & 頭 & $v$ & 石 & & & & 酸 & & 3 \\
\hline 頭 & $\pi$ & $\overline{5}$ & 渄 & バ & 毛 & $=$ & $\bar{j}$ & 下 & > & 灰 & & & & & & 马 \\
\hline 7 & べ & ザ & 頭 & ナ & 囊 & 生 & 敢 & 共 & 穜 & 水 & & & & & & 用 \\
\hline D). & カ & $v$ & $=$ & y & 中 & 仰 & $\bar{\tau}$ & $=$ & 効 & 亞 & - & & & & & E \\
\hline $\bar{\gamma}$ & $\overline{5}$ & バ & 由 & 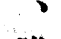 & 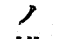 & 7 & 警 & 無 & $P$ & 麻 & & & & & & テ \\
\hline 足 & ザ & 驚 & $\bar{J}$ & 唯 & 排 & 失 & " & 數 & $y$ & 仁 & $U_{0}$ & 0 & 五 & ? & & 炎 \\
\hline$v$ & $N$ & 愕 & 多 & 此 & 泄 & シ & $=$ & 脫 & & 油 & 0 & 五 & 0 & 五 & & 症 \\
\hline
\end{tabular}


三○三著原誌雜會焭研事醫堂天順

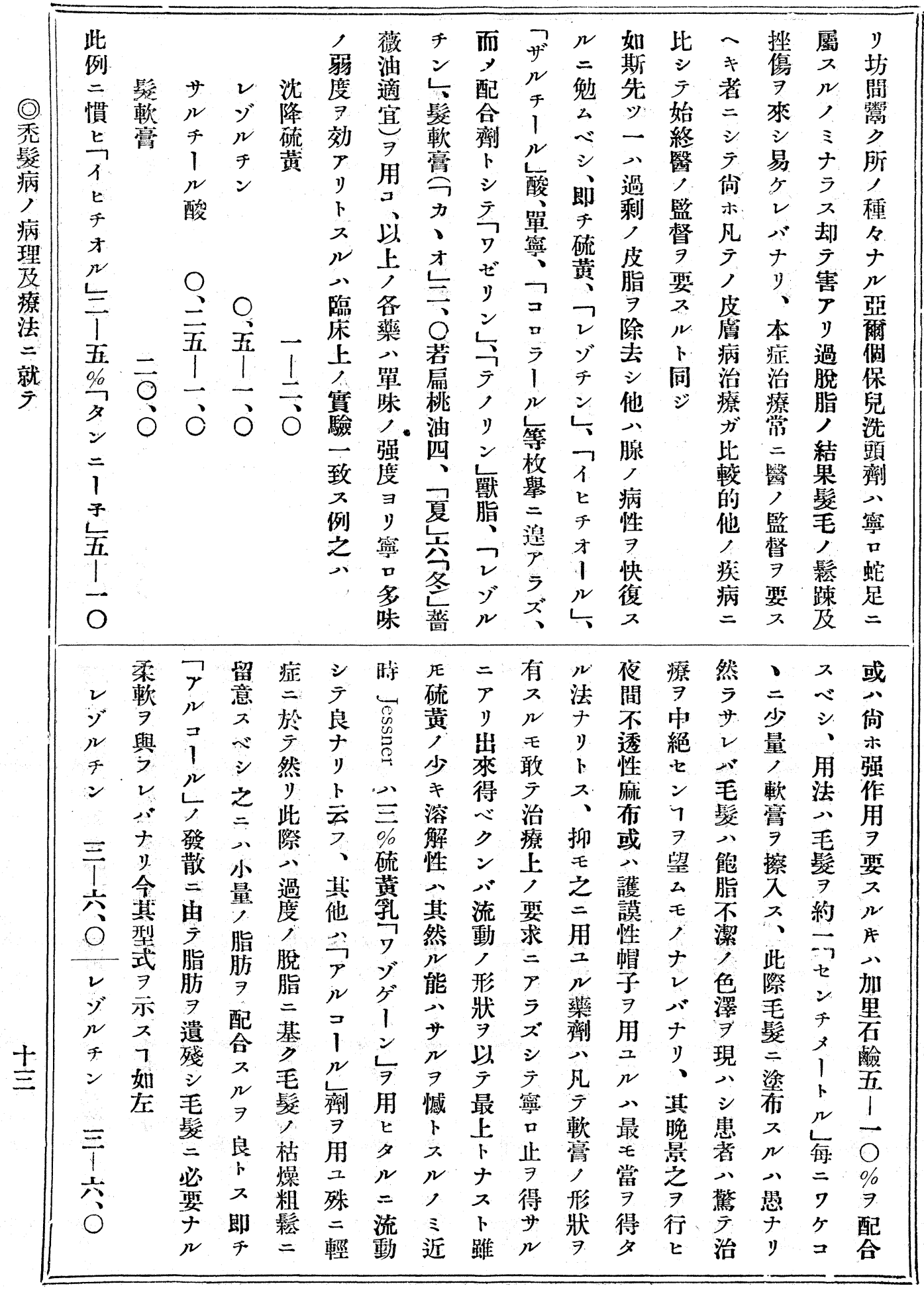




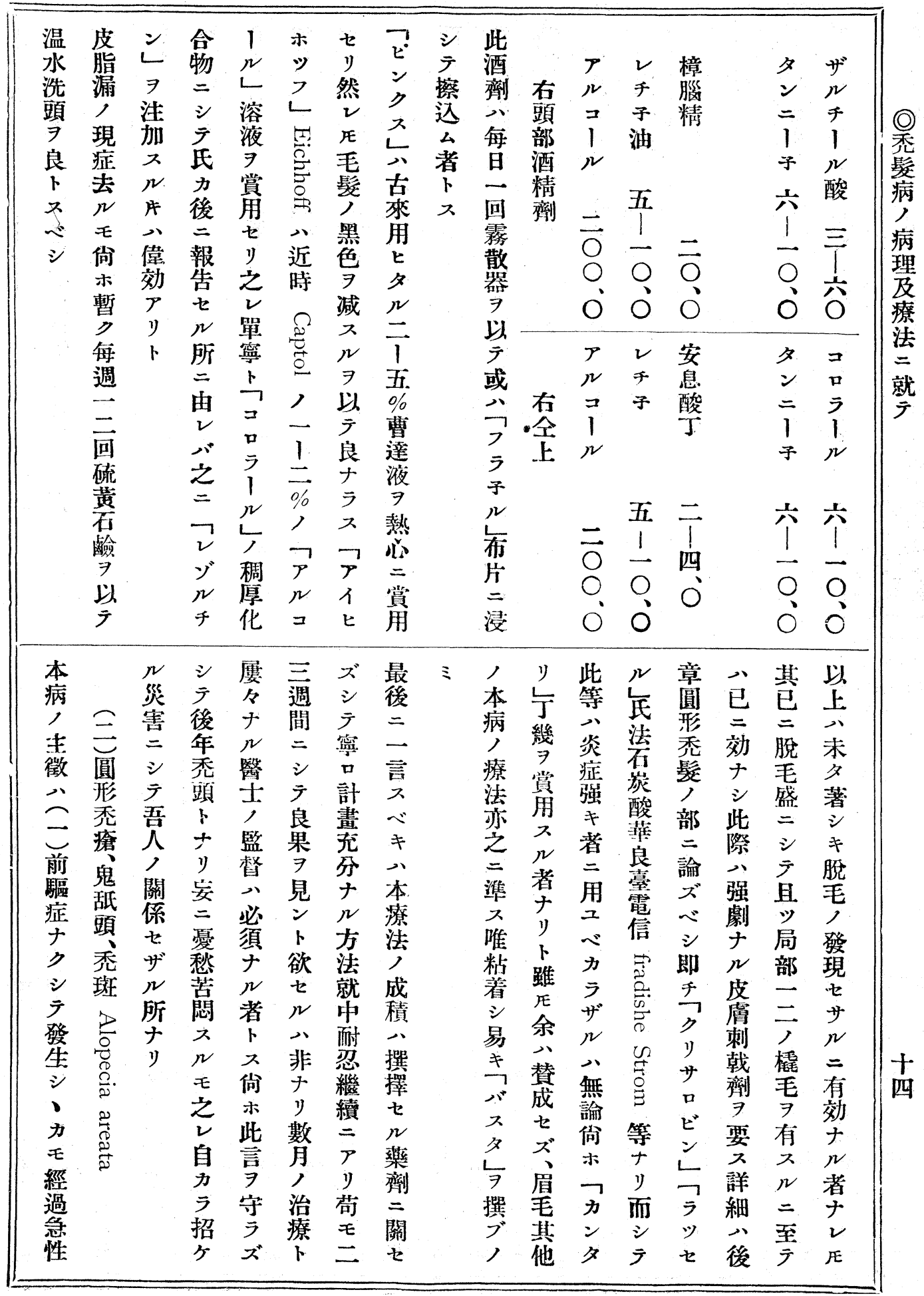




\section{五O三著原誌雜會究研事醫堂天順}

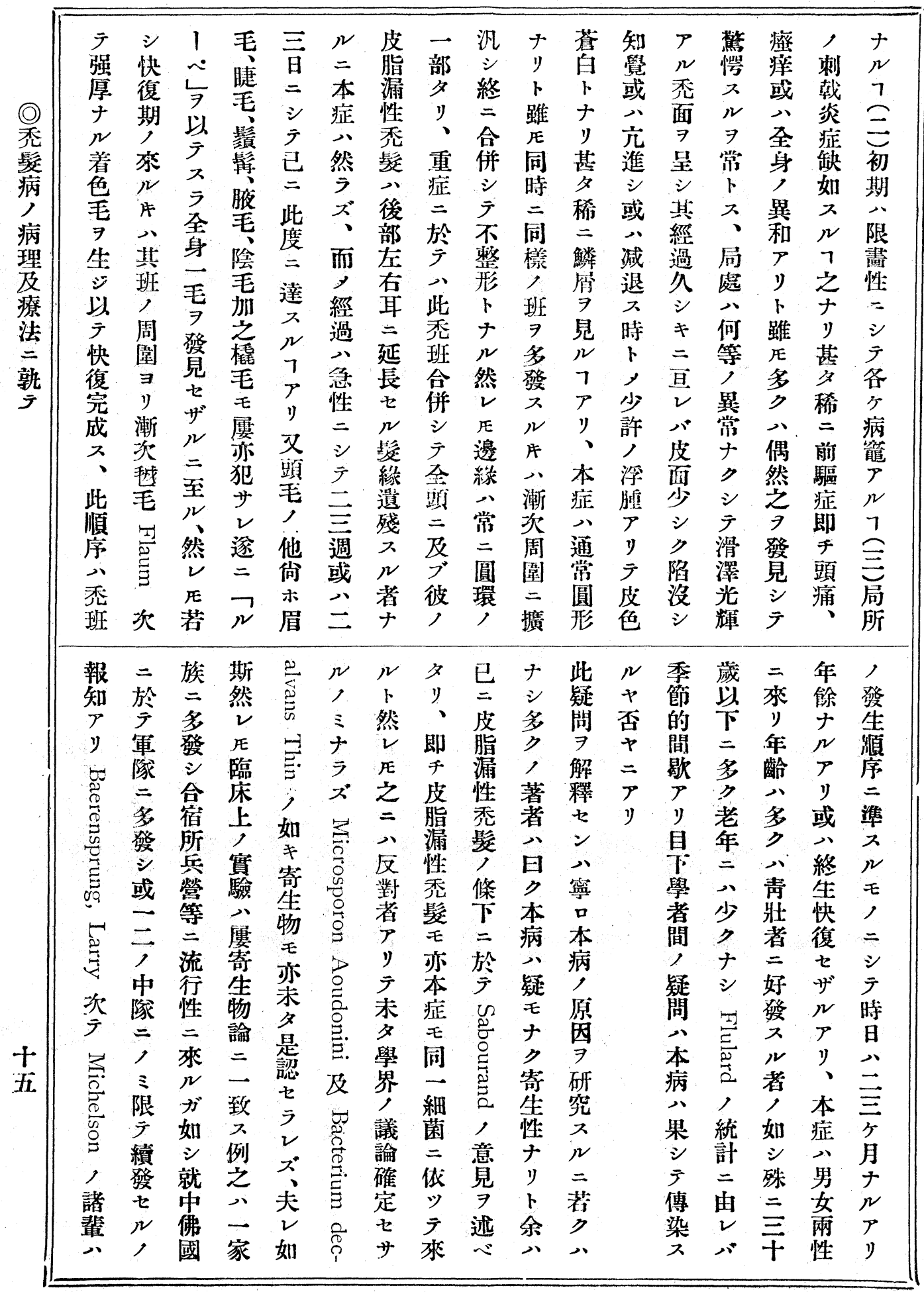




\begin{tabular}{|c|c|c|c|c|c|c|c|c|c|c|c|c|c|c|c|c|}
\hline$心$ & $\boldsymbol{\gamma}$ & 驗 & 䯱 & 隣 & , & 中 & 告 & 後 & 左 & 經 & 然 & $\neq$ & ズ & 7 & ナ & 想 \\
\hline カ & ラ & 3 & $=$ & 接 & 試 & + & シ & $=$ & 頸 & 證 & J & $\rightarrow$ & 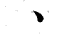 & 冠 & $y$ & $\sim$ \\
\hline ラ & ע & $N$ & 先 & ر & 駿 & 三 & 及 & 闹 & 部 & $\exists$ & 生 & 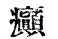 & 屡 & Ł & 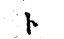 & ラ \\
\hline ザ & 又 & 處 & $\bar{y}$ & 部 & $=$ & 回 & $\kappa$ & 側 & 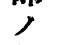 & 是 & 志 & 瘤 & 政 & シ & $\checkmark$ & b \\
\hline$N$ & 神 & ナ & 頭 & $€$ & 徵 & > & o & r & 腺 & 諗 & 危 & J & 經 & 厶 & 然 & 本 \\
\hline ナ & 經 & リ & 痛 & 佾 & シ & 本 & 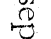 & 圓 & 厤 & t & 險 & 谈 & 家 & $v$ & $y$ & 症 \\
\hline リ & 性 & ' & 及文 & ホ & $\bar{\gamma}$ & 症 & $\vec{\sigma}$ & 形 & 手 & ザ & $=$ & 作 & 手 & ) & 宣 & 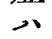 \\
\hline & $\bar{E}$ & 故 & 他 & 秃 & 此 & 7 & 八 & 秃 & 術 & N & 相 & 後 & $=$ & 滴 & $=$ & 寄 \\
\hline & $\gamma$ & $=$ & , & 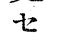 & $v$ & 發 & 猫 & 瑟 & $=$ & へ & 遇 & $=$ & 类 & 售点 & 臨 & 生 \\
\hline & $\overline{7}$ & 余 & 神 & 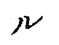 & 9 & 七 & 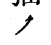 & $\exists$ & 於 & カ & シ & $-r$ & 過 & 䱜 & 床 & 性 \\
\hline & 2 & 輩 & 經 & $\Rightarrow$ & 批 & y & 第 & 發 & $\overline{5}$ & ラ & $\bar{\gamma}$ & $\overrightarrow{2}$ & 劇 & N & $E$ & $=$ \\
\hline & 卜 & $\rightarrow$ & 症 & 以 & 難 & F & 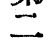 & シ & 上. & ザ & 本 & $\frac{0}{0}$ & , & 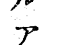 & 神 & $\gamma$ \\
\hline & $ノ$ & 暫 & 状 & $\bar{J}$ & シ & 云 & 頸 & 後 & 䫓 & v & 症 & & 精 & $y$ & 經 & ラ \\
\hline & 緮 & $\eta$ & 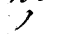 & 奎 & 月. & 7 & 斾申 & $=$ & 神 & $\not j$ & $\Rightarrow$ & ) & 触 & s. & 秃 & ズ \\
\hline & 昧 & 圓! & 前 & 然 & ツ & 外 & 經 & $\rightarrow$ & 經 & 如 & 程 & 如 & 感 & 然 & 戕 & シ \\
\hline & ナ & 形 & 驅 & 此 & 赫 & 然 & 矩 & 龂 & $\exists$ & シ & セ & $\neq$ & 動 & 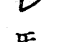 & & $\bar{J}$ \\
\hline & $N$ & 秃 & x & 恱 & 神 & $v$ & , & 側 & 損 & : & シ & $\rightarrow$ & $=$ & E & $P$ & 皮 \\
\hline & 推 & 堅 & $r$ & $\exists$ & 孫 & 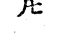 & 切 & $=$ & 㑺 & 近 & 献 & + & 由 & 此 & $=$ & 膚 \\
\hline & 定 & 中 & $\rightarrow$ & 排 & 障 & $\infty$ & 所 & $\mp$ & $t$ & 时 & 告 & 七 & $\bar{\gamma}$ & 證 & $\stackrel{\mathbb{Q}}{己}$ & 營 \\
\hline & $=$ & $=$ & 徍 & 眸 & 害 & 节 & $=$ & 分 & シ & O & $=$ & 奯 & 又 & 未 & 0 & 垁 \\
\hline & 瀮 & 八 & \& & Ł & $\exists$ & $\widetilde{\tilde{D}}$ & 由 & 佈 & $=$ & $\stackrel{\vec{C}}{0}$ & 徵 & $r$ & 1 & タ & تै. & 榊 \\
\hline & 足 & 笴 & 吾 & $y$ & 受 & & $\bar{\gamma}$ & $\bullet$ & $\equiv$ & 导 & ᄌ & 女 & $\mathbb{P}$ & 强 & & 經 \\
\hline & 七 & 生 & $\hat{\Lambda}$ & $\checkmark$ & $\widehat{5}$ & 八 & $\equiv$ & $N$ & 週 & $\stackrel{乛}{2}$ & $v$ & $\hat{f}$ & $\bar{c}$ & 固 & ᄀ & I \\
\hline & $サ^{2}$ & 性 & $j$ & 其 & 少 & 自 & $F$ & 7 & 間 & $\stackrel{\Xi}{\Xi}$ & バ & ガ & , & 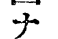 & 别 & 㜔 \\
\hline & $N$ & 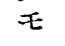 & 㥶 & 秃 & $N$ & 己 & 回 & 㪕 & $\gamma$ & 八 & 唃 & 突 & 如 & ラ & 名 & 害 \\
\hline ス & 適 & $=$ & $\overrightarrow{7}$ & 炎 & 易 & 恼 & と & ン & $\square$ & 分 & 拢 & ' & 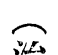 & 痒 & ナ & 本 \\
\hline 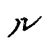 & 當 & x & リ & $\Rightarrow$ & $\eta$ & 其 & $F$ & $\pi$ & ビ & f & 毛 & 適 & 治 & F & N & 症 \\
\hline 洗 & , & $N$ & 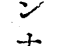 & 豫 & 皮 & 患 & 才 & F & $y$ & $n$ & - & 用 & 療 & シ & 所 & $\rightarrow$ \\
\hline 濯 & 處 & 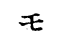 & L & 防 & 膚 & 及 & 1 & $y$ & 노 & 清 & t) & F & & 之 & ? & 圓 \\
\hline 物 & 置: & 每 & $=$ & $\gtrless$ & 竾 & 周 & נ & 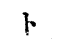 & 五. & 潔 & $\Xi$ & y & 其 & $v$ & 水 & 形 \\
\hline 等 & 7 & 日 & 從 & $\exists$ & 7 & 邀 & $\gamma$ & 는 & 1 & 法 & $\mathscr{\xi}$ & 何 & 原 & $\neg$ & 胞 & 限 \\
\hline 凡 & 望 & 醫 & $\bar{\tau}$ & 即 & 誘 & $=$ & $y$ & 3 & $\sim$ & 于 & & $v$ & 則 & - & 于 & 畫 \\
\hline$\overline{\bar{\gamma}}$ & $x$ & 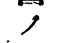 & 亞" & $F$ & 起 & 塗 & $F$ & ク & O & y & 7 & , & די & $\mathcal{N}$ & $\Rightarrow$ & 性 \\
\hline 着 & வ゙ & 監 & 筈" & 㛟 & $\pi$ & 縩 & $E$ & $\begin{array}{l}y \\
+ \\
+7\end{array}$ & $\%$ & 水 & L) & 療 & 殺 & $7^{7}$ & 亪 & 滇 \\
\hline 画 & ナ & 督 & 膠保 & 㫛 & べ & $\pi$ & $=$ & サ & 或 & 1 & F & 法 & 菌 & 及 & 色 & 濢 \\
\hline ス & リ & $\exists$ & J & $=$ & 5 & 此 & $\gamma$ & 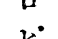 & $\therefore$ & 不 & 细 & $\exists$ & 劑 & $\therefore$ & $\exists$ & $=$ \\
\hline$N$ & $\checkmark$ & 要 & 輪 & & $v$ & 際 & ᄂ & 七 & $\sigma$ & 襝 & 厶 & 撰 & 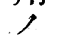 & บ & 呈 & シ \\
\hline , & 本 & $\pi$ & $\Rightarrow$ & 能 & バ & 泩 & 五 & $\frac{1}{7}$ & $\Xi$ & $\exists$ & $\begin{array}{l}N \\
7\end{array}$ & 擇 & 應 & $\begin{array}{l}\text { ズ } \\
\overline{7}\end{array}$ & t & $\bar{j}$ \\
\hline 不 & 療 & 之 & 用 & シ & ナ & 意 & م & \#! & ટ્ટ & 用 & 7 & $\pi$ & 筩 & ラ & ズ & 鱗 \\
\hline 快 & 法 & $\bar{v}$ & 1 & 校 & $y$ & 七 & 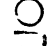 & $\dot{0}$ & , & 그 & 良 & $N$ & $=$ & ע & 毛 & 肩 \\
\hline $\boldsymbol{\gamma}$ & $\therefore$ & 刺 & $n$ & 間 & 、 & $\exists$ & $\nabla^{\prime}$ & ザ & 7 & へ & & $=$ & $\boldsymbol{\gamma}$ & 준 & 皮 & f \\
\hline$v$ & 局 & 战 & 7 & 閉 & 眼 & $\vec{n}$ & ゼ & $N$ & 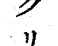 & シ & 지 & 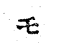 & ラ & 卢 & J & シ \\
\hline バ & 部 & 瓷 & 良 & 鎮 & 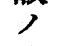 & II & y & チ & ザ & 次 & 之 & 先 & ズ & 異 & 切 & 之 \\
\hline 宜 & $\therefore$ & 症。 & F & 充 & 附 & $\begin{array}{l}y \\
+\pi\end{array}$ & 2 & 1 & サ & $\overline{\bar{\gamma}}$ & $=$ & \% & 2 & F & 迦 & $v$ \\
\hline シ & 勿 & 1 & x & 分 & 近 & サ & 八 & $N$ & $\nu^{\circ}$ & 先 & 次 & 患 & バ & $N$ & 切 & 皮 \\
\hline$\eta$ & 論 & 度 & م゙ & ナ & $\rightarrow$ & 4 & 八 & 酸 & & ๗ & ₹ & 部 & 皮 & 所 & 肩 & 脂 \\
\hline 虫 & 之 & $=$ & シ & $N$ & 殊 & t & $\dot{0}$ & & 3 & $\neg$ & 楸 & 及 & 膚 & & 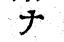 & 漏 \\
\hline 者 & $=$ & 應 & $\checkmark$ & 帽 & $=$ & $L$ & 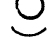 & 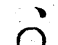 & ザ & $\eta$ & N & 周 & 刺 & & n & 性 \\
\hline$=$ & 接 & x & 何 & 或 & 結 & $\rightarrow$ & 7 & $\longrightarrow$ & 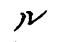 & y & $\therefore$ & 邊 & 戟 & & 又 & 卜 \\
\hline 预像 & 觝蜀 & $N$ & $v$ & $\rightarrow$ & 膜 & 容 & 每 & イ & ぺ & サ & 充 & ' & 劑 & & 瘙 & 異 \\
\hline
\end{tabular}


七O三著原誌雜會究研事醫堂天順

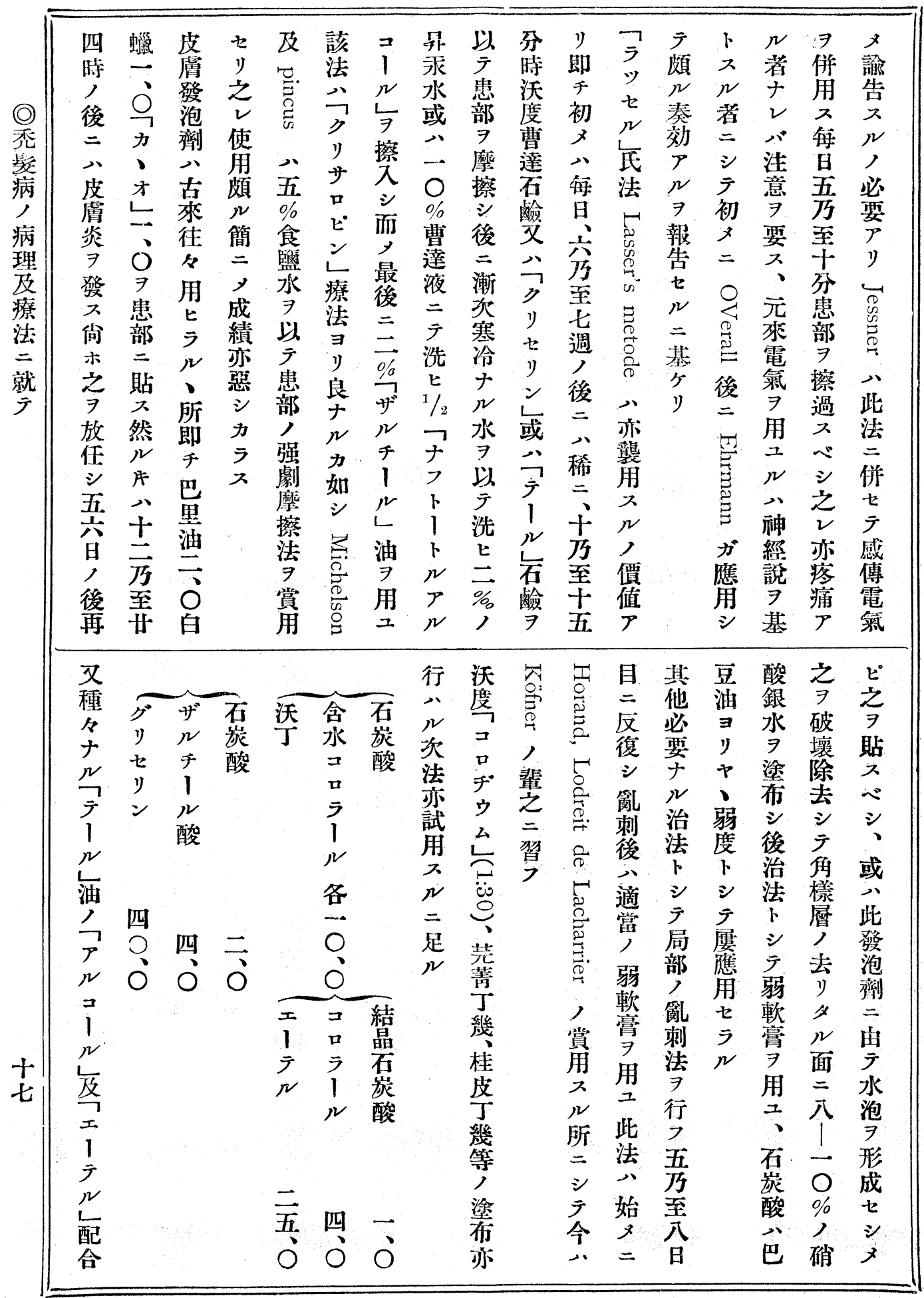




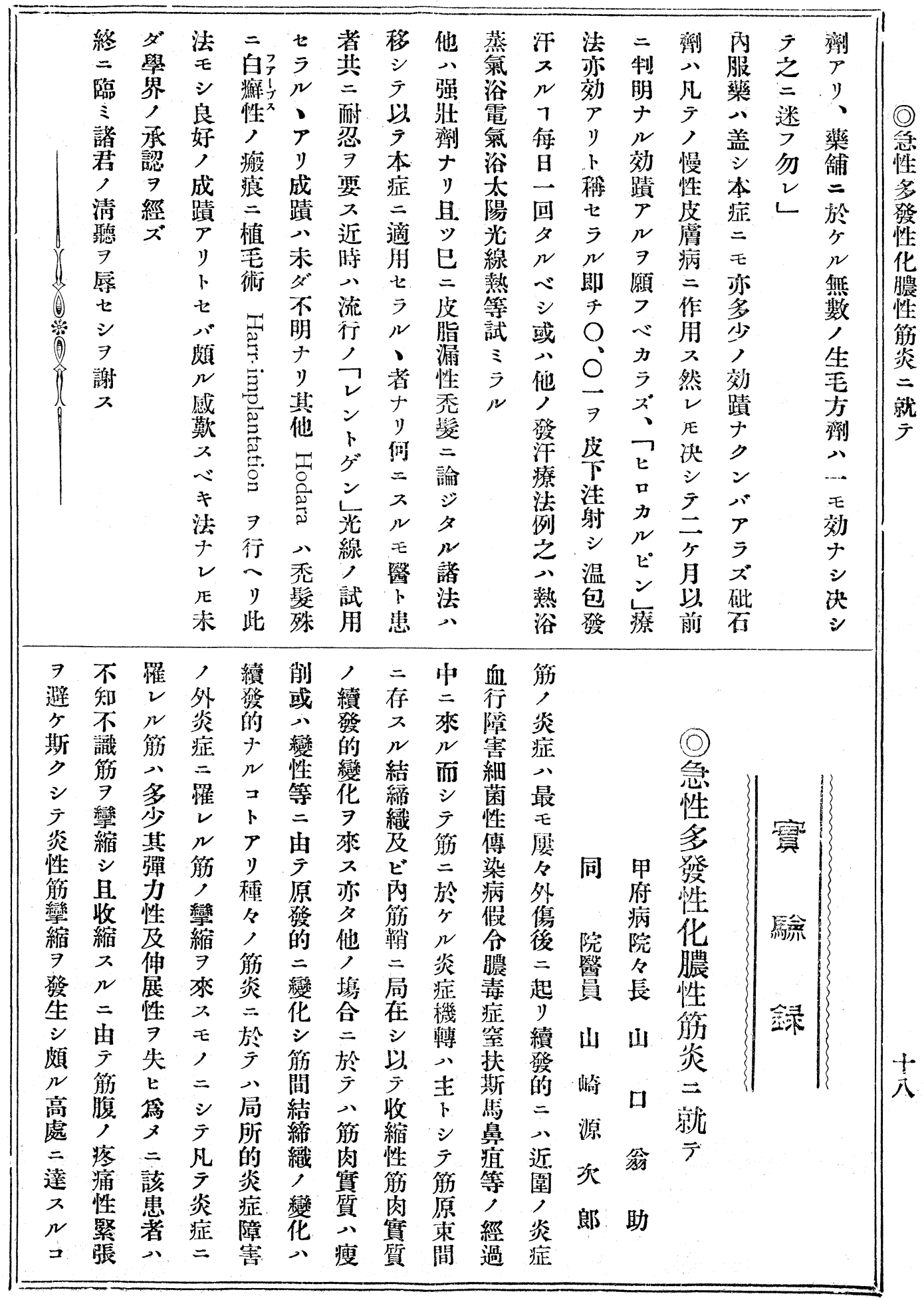

